Bu makaleye atıfta bulunmak için/To cite this article:

YAȘ, E. (2021). The Linking Between the Emerging Market Economy and Human Character in Volpone of Ben Jonson. Atatürk Üniversitesi Sosyal Bilimler Enstitüsü Dergisi, 25 (Özel Sayı), 213-230.

\title{
The Linking Between the Emerging Market Economy and Human Character in Volpone of Ben Jonson
}

$\operatorname{Emin} Y A S^{(*)}$

\begin{abstract}
Social developments/events of three different periods (Elizabethan Period (15581603), Jacobean Period (1603-1625) and Caroline Period (1625-1649) might have had great impact on Ben Jonson's writing the play Volpone. In this qualitative study (conducted with literature research on the topic), Volpone through which he best reflected his corrupted society at that time will be examined. The play will be analysed to illuminate the native features related to the market economy. The economic sight based on commodity has such a great power in changing the characters of the people, losing their morals because of their greed towards the power and wealth during the mentioned period. Another point to be discussed is to reckon whether Ben Jonson as a Dramatist had contrary opinions against the developing capitalist world. In the study, it has been found that the play of Volpone (the fox) depicts one of the best evidence how the characters can be changed through materialism. As a main character, he is a wealthy Venetian nobleman and exceptionally cunning, who devises a plan (pretending to die) with the assistance of his henchman (Moscal fly) to exploit his relatives waiting to be an heir of him. The play shows how his relatives flatter him and give him the most expensive gifts. He deceives each of them at the end. The play draws attention to the materialistic power of the 16th century.
\end{abstract}

Keywords: Ben Jonson, Volpone, drama, Renaissance, monopoly economy

\section{Ben Jonson'ın Volpone'sinde Gelişen Piyasa Ekonomisi ile İnsan Karakteri Arasındaki Bağlantı}

Öz: Ü̧̧ farklı dönemin (Elizabeth Dönemi (1558-1603), Jacobean Dönemi (1603-1625) ve Caroline Dönemi (1625-1649) toplumsal gelişmeleri/olayları Ben Jonson'ın Volpone oyununu yazmasında büyük bir etki yapmış olabilir. Bu nitel çalışmada (konuyla ilgili literatür araştırmasıyla gerçekleştirilmiştir) o zamanlar bozuk toplumunu en iyi yansittığ incelenecektir. Oyun, piyasa ekonomisiyle ilgili yerel özellikleri aydınlatmak için analiz edilecektir. Emtiaya dayal ekonomik görüss, sözü edilen dönemde güç ve servete olan açgözlülüklerinden dolayı insanların karakterlerini değiştirme, ahlaklarını kaybetme konusunda büyük bir güce sahiptir. Tartışllması gereken bir diğer nokta, bir Drama oyun yazarı olarak Ben Jonson'ın gelişmekte olan kapitalist dünyaya aykırı görüslere sahip olup olmadığını değerlendirmek. Çalışmada Volpone (tilki) oyununun karakterlerin materyalizm yoluyla nasıl değiștirilebileceğinin en iyi kanıtlarından birini gösterdiği tespit edilmiştir. Ana karakter olarak, zengin bir Venedik asilzadesidir ve son derece kurnazdır, uşăgının (Moscalfly) yardımıyla kendisinin varisi olmayı bekleyen akrabalarını sömürmek için bir plan (ölmüş gibi yaparak) yapar. Oyun, akrabalarının ona nasıl dalkavutluk edildiğini ve ona en pahalı hediyeleri verdiğini gözler

${ }^{*}$ Dr. Öğr. Üyesi, Batman Üniversitesi Fen-Edebiyat Fakültesi Batı Dilleri ve Edebiyatları Bölümü (e-posta: emin.yas@batman.edu.tr) (DD ORCID ID. https://orcid.org/ 0000-0001-6813-1160

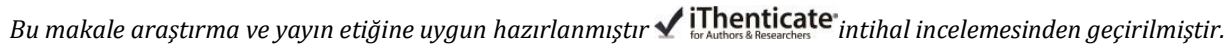


önüne sermektdir. Her birini sonunda aldatır. Oyun 16. yüzyılın materyalistik gücüne dikkat çekmektedir.

Anahtar Kelimeler: Ben Jonson, Volpone, drama, Rönesans, monopol ekonomi

Makale Geliş Tarihi: 15.05.2020

Makale Kabul Tarihi: 14.11.2021

DOI:10.53487/ataunisosbil.737815

\section{Introduction}

After Shakespeare's death, Ben Jonson, poet and playwright, became the leading literary figure of the James I era. However, Jonson's aesthetic mirrors the Middle Ages rather than the Tudor Dynasty: his characters embody the Theory of Four Fluids. According to this medical theory, behavioural differences stem from the dominance of one of the "body fluids" (blood, mucus, yellow bile, black bile) over the other three; these liquids correspond to the four elements in the universe: air, water, fire and earth. This facilitated Jonson to exemplify such differences (of creating stereotypes or stereotypes). Volpone, a wealthy and childless Venetian nobleman, is, as his name suggests, extremely cunning. With the help of his henchman named Mosca (Fly), he devises a plan to exploit his relatives, who are looking forward to his death. The target of this research is to try to find out a relation between the Play Volpone and the capitalism, which was appearing at that time. The work is limited to the literature written in that period and the play itself.

It is worth talking, in brief, about some historical developments in England at that time. There were the Elizabethan, Jacobean and Caroline Ages through which Ben Jonson went. The country underwent social, political and religious problems which came to life because of the changes in the authority. Ben Jonson touches on them mostly in his plays. On the other hand, religion had an important position in the Renaissance England, possessing various impacts such as finance, policy and social life impacts. Likewise, there was a standstill between the Catholic and Protestant parts profoundly in the reigns of Queen Mary and Queen Elizabeth. Issues like financial policy, in the reigns of James I and Charles I, were the reason Ben Jonson included these in his literary works.

A vast majority of changes was seen in England. The growth of the market economy was spreading in the early modern Europe. England was not an exception. It was a menace for nearly every part of the society that consisted of a status level. At the same time, it can be said that the rulers of the period had a tendency to rely on religion.

Various problems are to mention: monopolism, the patent system and case drainage, etc. It is widely accepted that the monopoly system was/is the kernel of the capitalist economy which was predominant at that age. Ben Jonson recurrently refers to this so called monopoly system that appeared under the regime of Queen Elizabeth while giving certain benefits to preferential men "as a means of revenue to the crown or as a reward for services rendered" (Miller, 1907: 2). On the account of the fact that the reign grew its revenue thanks to these offerings, and this way, the economy became quite more invigorated, many monopolies were established quickly, and the process continued more and more. Nevertheless, these institutions could not help the community have the 
affluence. Conversely, it caused "raising prices, debasing quality and attributing unemployment" (Kent, 2007: 217). As the rule of King James I allowed monopolies to have illogical patents with the aim to boost the quantity of monopolies, people exploited this arrangement.

In connection to the mentioned progress, London converted to the hearth of commerce internationally. The business in glamorous luxury properties had an important role in such progression. The perception of luxury and financial, social and cultural modifications occurred as enchantment on the one hand and scepticism on the other hand inside the society.

Ben Jonson got motivated to portray the current London and the people living there with a 'realistic' standpoint. The realism at that time is "a realism of subject matter, a social realism" led by the "social dynamic" in the theatre (Hayness, 1992: 6). In order to deliver severe problems, he sees comedy as a method to fulfil the duty, considering comedy a tool of bringing debated social matters on the agenda. Such duty should show the malformation of the period.

London and Venice were two cities used as settings in the plays of Ben Jonson. Brian Parker indicates the similarities between Venice and London showing that they were maritime trading cities. So, later, he handles English travellers Sir Politic Would-be and his wife in the play with the aim of giving in which manner Ben Jonson set up similarities between England and Italy, maintaining that they (the Would-bees) "act as a link between the exotic plot and setting on one hand and the English audience on the other" (Parker, 1999: 20).

Alongside his satires about ongoing issues, social matters and follies in the period, he was an educated classist. Some critics like Herford C.H. and Simpson P. (1925: 121) comment that, among his colleagues, Jonson was unusual in being appropriate and demonstrating his era named the Elizabethan era: 'He had grown up in the very heart of Elizabethan England", knew every comer of "picturesque London" and had "more numerous and intimate relations in Court'.

Volpone of Ben Jonson, which is social satire, displays how human beings get the ability to grow in a beastly nature because of an evil manner and wicked endeavours as they are no longer involved in carrying out labour based on sacred ethics. Jonathan Haynes (1992: 24) maintains: "Jonson's great legacy from the morality" is his adaptation of "a structure of examination" and "judgment of social behaviours". Before dealing directly with the play Volpone, the reader shall be provided with a survey of the economic aspects of Jacobean England. In the first instance, a description of life in London shall be aimed to be given in detail. 


\section{The Plight of London}

There are a number of observations and descriptions of Jonson's London available. London was a bustling city with tremendous commercial activity. For example, the author, John Lyly, praises London as a place famous for both the beauty of its buildings and its infinite richness. It is a city full of variety of all things that excel other cities in the world, a thriving metropolis with numerous large storehouses, and a market to all Europe (Bevington : 1979).

Fynes Moryson (Venables, 1970: 1) remarks upon the many stately palaces and fine mansions of noblemen built along the river Thames, which impress the observers that pass by. He also speaks of the splendour to be found in the shops and in open markets, the wealth of the noblemen and chief citizens, their magnificent carriages and fine clothes. London was at the heart of western trade because of the discovery of America, and since religious wars had devastated continental Europe and especially the Netherlands, the city had drawn ahead of Amsterdam as a centre of commerce. This commercial vitality was recognized and appreciated by all travellers and merchants from abroad.

Seventeenth century London was a large, fast growing and excellent city, a mighty city of business, the most important in the whole kingdom. Most inhabitants were employed in buying and selling merchandise and trading at almost every corner of the world. It was a very a populous city. Furthermore, Thomas Decker (Graham, C.B.: 1947) as a native Englishman, also describes the bustle of activity in the streets that the streets were so narrow that when a cart passed through, there was hardly any room for pedestrians to avoid the filth flung up by the wheels. Hammers were beating in one place, tubs being carried in another, pots clinking here and there, porters sweating under burdens, and merchants' men bearing bags of money. It is a city full of tradesmen. All are as busy as country attorneys. Many visitors were impressed by London-Bridge. The goldsmiths who lived there were also bankers and among the richest men in the city. The merchants were so rich that they could show off their wealth in public with impunity. Ownership of land passed from families of noble blood to men of trade, and was usually recovered only by marriage, if at all.

The demand for agricultural labour fell steadily since most members of the landed gentry turned their attention to industrial commerce and trade. As a result, the country tenants and servants of the destitute courtiers often found themselves homeless and without hope of work. They had no alternative except to try to escape from their poverty and starvation by flocking to London, where they inevitably ended up in dark slums. Accordingly, the number of the poor and destitute grew dramatically. Social pressure, poverty and hunger destroyed fastidiousness, and necessity blunted moral sense. Scavenging and petty crime were among the most common means of subsistence, pimping and prostitution almost the only trades to be had. Rich men had a big impact on the decision of the court. For women, it was a life that promised only humiliation, disease and early death, though it had its moments of gaiety and crude luxury and sometimes brought rich pockets to be picked. 
The Linking Between the Emerging Market Economy and Human Character in Volpone of Ben Jonson

\section{The Growth of the Market Economy}

It is very important to say something about the governing of the country in this relation and the structure of the society regarding the development of the capitalist enterprise. Queen Elizabeth, a skilful and astute politician, had served her country's need so effectually and managed its economic and foreign affairs so well that England could develop and grow rapidly. She had managed the state so efficiently that by the time her long reign was over, her people had outgrown their need for her and her kind. Thanks to her skilful management, security and peace, which are necessary for economic growth and prosperity, followed by the establishment of a firm government, guaranteed freedom of activity, which supported the enterprising attitude of the capitalist. At first, the growth of the industry was hampered by political disputes during the last years before the revolution, and by the uncertainty of the new conditions during the first years, but after about 1691, it went forward with redoubled strength (Stout M., 1988).

The most obvious characteristic of capitalist organisation is the division between the employer who owns the instruments of production and the finished goods on the one hand, and the hired workman who owns nothing but his labour on the other hand. In the Middle Ages, many gild masters were capitalist, but the relationship between the labourer and the owner of the trade was more or less harmonious. The emergence of any form of capitalist organisation is dependent on two factors, the existence of a wider market than the medieval local community and an adequate supply of money. Further capitalist development also presupposes a permanent class of labourers who have no choice but to work. Some of these conditions were present in the Middle Ages. Commerce is necessarily capitalistic.

Capitalist finance may be traced back to the Middle Ages, to the Papal tax system, to Italian banking in the thirteenth century and to the credit system in use in the great medieval fairs. England was laid upon the foundations of European civilisation; large scale commerce and capitalist industry were very big. Sixteenth century capitalism was mainly a development of circumstances that were previously there. We may state that the developments were provided by discoveries. It should be pointed out that the inflow of American gold and silver into Europe hastened the disruption of the medieval economic arrangement. American gold and silver were diffused throughout the world, particularly in England and France. The effect of Spanish - American treasure in stimulating capitalist enterprise is clearly seen in England. Prices in 1650 were approximately three times what they had been in 1500 . The important point, of course, is not merely that prices rose but that they were only slowly followed by rents and wages. The process that, in effect, deprived labourers and landlords of a large part of their incomes provided undreamed of opportunities for the capitalist. We find, as might be expected, that during the seventeenth and latter part of the sixteenth centuries, France, the low countries and England were seeing such genuinely capitalistic phenomena as systematic mechanical invention, company promotion and speculation in the shares of financial and trading concerns. The larger proportion of the fruits of the economic advancement and capitalist accumulation of the Elizabethan and Jacobean age was 
accumulated in the hands of the profiteer instead of the wage earner. There had never existed such a prolonged and rich opportunity for the businessman, the speculator and the profiteer in the history of the modern world. Modern capitalism emerged in these golden years (Stout M.: 1988) Furthermore, in mentioning capitalist finance and the growth of a money market, these things were important: The rise of large-scale finance, which is a characteristic of the sixteenth century, was of course largely due to the increased commercial and industrial activity that has still to be considered. However, the rise of an international money market was itself one of the first causes of economic expansion, since the force of money in determining the course of the world 's history meets us at every turn in this period. The influx of capital that was necessary for that expansion was largely directed by international financiers.

Other forms of enterprise, privatising, discovery and colonisation have to be mentioned here, since in their methods and results, they were all closely related to the commercial development of the period. Not only was foreign trade occasionally allied with freebooting, the various activities of the Elizabethan seamen afforded investment, but others besides merchants shared in the commercial profits. The formation of jointstock companies provided an opportunity for anyone with capital to invest, and from 1600, the sale of shares became increasingly common. Privateering, discovery and plantation companies were largely composed of courtiers and noblemen. Elizabeth herself invested in Drake's syndicate (Rorabacher: 2017: 101). As joint- stock companies showed, there were inevitably very considerable fluctuations. In the whole period, the sum of the gains from commerce was very large indeed, but individual investments might well be unlucky. What the increase of joint stock activities calls attention to was the spread of the speculative temper, the willingness to gamble in the hope of large returns. Substantial profits in trade were limited by a relatively narrower part of the society. The financial conditions, at the same time, intensified poverty.

Large dislocation in the cloth-exporting trade was caused by the expulsion of the Merchant Adventurers from Germany in 1597 or Dutch competition in the reign of James I impacted immediately on the clothiers and those whom they employed. At the end, they were not able to keep their workers fully occupied the whole year round. Profits increased, but labour discontent and the growth of the "class war" were violently stimulated, in particular, in the woollen industry. Under Elizabeth and James I, many industries such as the iron, soap, glass, wire, copper and coal industries were established, and they were organised along capitalist lines. They required an initial capital outlay and possession of capital to finance operations. Those who controlled the industry by owning the material or the material and instruments of production were not as a rule craftsmen themselves, and they engaged in the industry with a view to the profits of a national market. The history of London companies in the sixteenth century and the early sixteenhundreds shows how far the older industries were subject to a parallel development.

The monopolies exercised by the gilds were very different from the monopolies of the reigns of Elizabeth and James I. The former monopolies were possessed by groups of traders or craftsmen, while the latter were held by individuals as well as corporations. They were national monopolies in a few hands, and, as often as not, their purpose was 
economic exploitation without regard for the community. It has been claimed that the attempts to build up the aluminium industry as a government monopoly furnish interesting illustrations to anyone who believes in the unfitness of the government to administer industrial undertakings (Miller, 1907). Rather, this and similar undertakings provide a comment on protected private enterprise.

In a period of capitalist expansion, in which the tradition of state regulation was not implemented by an efficient civil service, protection of the public good was inevitably made to serve the interests of private profit. The history of aluminium monopoly shows the characteristic features of early industrial capitalism. There was accumulated capital to be invested, and there was a demand for industrial development, but there was neither understanding of the new economy nor control. The aforementioned intense economic activity that gave rise to a class of new men, clothiers, financiers, merchants and entrepreneurs. These individuals did not owe their power to the possession of land, like the old feudal nobility, or to political-administrative skills.

There were new men, of course, in the middle ages, but from the mid-sixteenth century onwards, there were far greater opportunities for a greater number, and the opportunities were not only economic. The new possessions of the rules of Elizabeth and James I received social and political power and induced a dominating effect on the course of the history of England. In all the larger towns of England, and, as will be seen, in the country, there were men who knew how to grasp the opportunities offered by rising prices, by an expanding trade and industry, though for the most part, details of their career are not available. They exceed others in policy and industry, for utilising their trade and grounds, and after the rude and arrogant manner of their wild country, they outshine others in terms of wisdom and wealth. They loathe old fashions if they can hear of a new, more commodious rather effecting novelties than those associated with old ceremonies.

\section{Jonson as Dramatist}

At the beginning of the seventeenth century, it seemed to many that on all levels of society, greed and vice were the central moving force. The same attitude is reflected in Volpone and the Alchemist. Both plays deal with a relentless striving after the acquisition of wealth. However, these plays do not attack the society. They rather show how greed makes men immoral and stupid. Jonson's satirical plays mock the condition of the society. They show us people from a variety of social backgrounds, yet all infected by greed and unscrupulousness, which seem to be characteristic of the whole society.

In depicting Venice, Jonson paints a picture of the people and their amorous lifestyle, their relentless pursuit of power and influence. They entertain strangers and are willing to sell their souls for material gain. Venice's reputation for depravity was based largely on the belief that all Italians were politically unscrupulous and immoral. Venice was a symbol, a token for the commercial society at that time. Jonson's most famous play, Volpone, which takes place in Venice, was written during the most productive period of 
his life, from 1606 to 1614, when Jonson wrote his great comedies. The other great plays were The Silent Women, and the Alchemist and Bartholomew Fair. Later, he wrote other plays, but none of them were as well-written as these four.

In spite of the fact that we know very little about his personality, it is well established that he was intransigent, combative, overbearing, opinionated and arrogant, but all these things could be justified (Sidney P., 1906). We should remember that we know these things only from William Drummond, Jonson's biographer. Jonson stayed with him at the end of his walk from London to Edinburgh in 1618. He was a friend of Jonson, and he held him dear.

Many readers might experience uncertainty and disappointment at their first acquaintance with Jonson's comedies (even the intellectual reader of that time was also acquainted with the ancient Roman works). This is largely due to the fact that Jonson's plays are quite different from anything his contemporaries have produced. For example, in contrast to his contemporary, William Shakespeare, Jonson's comedies are not romantic, but rather vacillating between realism and satire. Jonson was an erudite and scholarly man. He was influenced by classical ideas about drama, but he developed his own style, freeing himself from the rigid practice of the ancient poets. We may see the extent of his debt to the Latin comedies of Plautus and Terence that were read, translated, imitated and acted at schools and universities. Jonson often read Horace and made two translations of the Art of Poetry, from which Renaissance critics derived their principle of decorum. The view of the function of comedy was entirely orthodox in Jonson's time. Sometimes, his words might be applied to satire as well as to comedy." Comedy is an imitation of the common errors of our life, which represented in the most ridiculous sort that may be" (Venables, 1970: 13). These widespread mistakes in of our life, the weaknesses and follies of men, are continually targeted by Jonson.

Despite all the lightness of the end of the prologue, his famous play Volpone depicts much evil and untruth, not merely folly and error. This important aspect, this seriousness not found in Latin comedy, seems to be inherited from the English tradition of morality. In the Alchemist, the individual man, is the central figure, not the society. It is a late example of the English morality play. Latin comedy and English morality contributed to Jonson's style. His characters are neither the type figures of the Classical period nor the personified abstractions of morality plays. Jonson's personae are not like those of his contemporaries. Jonson's chief concerns are always the moral, not psychological questions. Like all artists of the Renaissance, Jonson sought to illustrate moral wisdom, not scientific knowledge. He held a mirror up to nature in order to reflect reality. Jonson is comparable to Shakespeare only in this respect. However, in their handling of plot, in their treatment of character and depiction of complex social elements, these two men were quite different. The life of the Jonsonian character is remarkably predictable and uncomplicated.

Along his career, Jonson was impressed by the market economy emerging in the Europe of the Renaissance. He was captivated by the new human identity categories that were being created by the market economy (the role of merchants, bankers, financiers 
The Linking Between the Emerging Market Economy and Human Character in Volpone of Ben Jonson

and entrepreneurs), and he was clearly unsettled by the new forms of corruption and vice endemic to proto-capitalist life. Bartholomew Fair gave Jonson an opportunity to dissect the lawlessness of the marketplace into details. From a traditional religion and politics perspective, the market may look lawless, but Jonson discovers the case that it may obey its own laws. With an anticipation of free market economics that is remarkable, he seems to comprehend that the market may be a self-regulating mechanism that is possible to bring peace to a society which otherwise appears to be destroying itself within conflicts in religion and politics. For all its faults, the market, in Jonson's portrayal, addresses the deep-seated necessities in human nature, and ultimately, he appears to comprehend the worth of the freedom it provides, not to mention that freedom is compatible with its own kind of order.

As his literary career went on, Jonson did everything he was able to for escaping the world of commercial theatre, above all, turning to aristocratic and royal patronage as an alternative to his bourgeois source of making a living in the business of entertainment. He wrote poetry looking for aristocratic patrons, and even in his career in drama, he switched back and forth between writing for public theatres and writing for the royal court. Besides the financial advantages of writing for the court, Jonson appears to have been drawn by the potential of composing with aristocratic taste in mind, rather than the lower and middle-class taste that triumphed at commercial theatres.

He appears to take the side of the aristocracy and its life of feudal privilege rather than the emerging middle class and its life of money and commerce. It should be kept in mind that even (and especially) in Marxist terms, capitalism was the progressive driver in Jonson's day, working to dissolve centuries of antiquated feudal privilege and unleash forces that were productive to unseen extents. Jonson substantially leans towards opinions that would be developed in time by economists like Adam Smith in favour of free markets. The fact that an unregulated market may have its drawbacks and drawbacks is not in itself evidence that a regulated market will not have its drawbacks and shortcomings as well, and perhaps end up creating even worse circumstances.

In prior plays like Volpone and the Alchemist, Jonson had dealt with the ways where the emerging market economy itself was a revolutionary force, a threat to upset the settled order of the society, and in particular, to overthrow the social hierarchy by turning the poor rich and the rich poor. However, Jonson, in Bartholomew Fair, seems to reevaluate his opinion on the social impact of the market economy, or at least refine it. Jonson's past in the theatre, in fact, placed him in a perfect position to evaluate the question of government regulation of the economy, or of the law versus the marketplace. His new-found sympathy for the marketplace appears to have come from a new understanding of the way his world of theatre was inextricably intertwined with the emerging market economy of his time. 


\section{Jonson's Volpone}

Connecting all the conditions and cases given above in the life of the people in that time, we may now speak about Volpone. In Volpone, Jonson makes a world of limited range but universal affinities. The attention is focused almost entirely upon the greed and credulity it provides. It shows us that avarice can infect as a power and quite pervert human nature, destroying its humanity, nullifying its intelligence and banishing all dignity and worth. He shows that through the character types. In order to be his heir, all of his relative flatter him and gives him expensive gifts; not only gift, Voltore donates bestows all his wealth to Volpone. Corvino brings his wife, a young woman, to Volpone's bed with his own hand for winning his favor.

Each characters was confident of his power to deceive and exploit others, and remarkable for his capacity to deceive himself. The three would-be heirs Voltore, Corbaccio and Corvino are dangerous and abhorrent in their villainy. They are absurd and deluded in their expectations and blind in their credulity. Volpone delights in their self-deception. He considers himself the master of intrigue, but he is absurdly susceptible to Mosca's flattery. Mosca sees that he can outwit and ruin his master. Volpone's house is the heart of the world in which Volpone and Mosca function. By adjusting the relationship between his subject matter and his language, Jonson can provoke a range of reactions in the audience.

He opens with a scene in which the relationship between language and matter is astonishing in its inversion of moral values. Jonson treats it as literally true in displaying Volpone's worship of gold.

“................. Thou art virtue, fame,

Honour, and all things else. Who can get thee,

He shall be noble, valiant, honest, wise - “(I i 25-27)

The power he attributes to gold is godlike and life-giving. In his eyes, it is the origin and superior of virtue, honour and good name, all worthy qualities. Mosca concludes this amazing rearrangement of values,

“ .riches are in fortune

A greater good than wisdom is in nature." (I i 28-29)

The value of gold is set above human relationships. According to Volpone, it is:

"All style of joy in children, parents, friends,

Or any other waking dream on earth." (I i 17-18)

Volpone boasts of his mastery in manipulating others for his own gain:

"True, my beloved Mosca. Yet, I glory 
The Linking Between the Emerging Market Economy and Human Character in Volpone of Ben Jonson

More in the cunning purchase of my wealth

Than in the glad possession, ..." (I i 30-32)

Yet he is himself the first character to be fooled by Mosca's fulsome's flattery

"But your fine, elegant rascal, that can rise

And stoop, almost together, like an arrow;

Shoot through the air as nimbly as a star;

Turn short as doth a swallow; and be here,

And there, and here, and yonder, all at once;

Present to any humour, all occasion;

And change a visor swifter than a thought,

This is the creature had the art born with him;

Toils not to learn it, but doth practise it

Out of most excellent nature: and such sparks

Are the true parasites, others but their zanies" (III i 23-30)

Jonson keeps alive and extends his fuller and deeper satire, which has Mosca and Volpone as its chief objects, by exploiting these different levels of understanding.

Volpone reminds us of his own hunger for wealth when he urges his parasite: ".

$$
\text { .O, there spoke }
$$

My better angel. Mosca, take my keys,

Gold, plate, and jewels, all's at thy devotion;

Employ them how thou wilt; nay, coin me too,

So thou in this but crown my longings, Mosca!" (II iv 20-24)

As Corbaccio is ready to sacrifice his inheritance in the hope of being Volpone's heir, so, Volpone will throw all the treasure he has amassed into the attempt to enjoy Celia. Like Volpone, Corvino is enslaved by passion, and in scenes II $v$ and II vii, we are shown how it has made him less than human. He is horrifying in treating his wife as no more than another gift that may win him Volpone's favour, the direct result of his greed. This deprives him of the dignity of human rationality. It is clear in Act III that Bonario thinks in terms of right and wrong, not profit, and is dangerous company for Mosca. Volpone, 
too, can now be seen as less secure than his confident trickery has so far suggested, and in III $i v$ we find him the victim of an unexpected reversal when Lady Politic Would-Be returns, and her knock on the door sends him to the refuge of his disguise and bed.

The fact that Celia alone among the people present sees the complete inversion of values that the episode represents, demonstrates how widespread the corruption is.

"Oh God, and his good angels! whither, whither,

Is shame fled human breasts? that with such ease

Men dare put off their honours, and your own?

Is that, whichever was a cause of life?

Now placed beneath the basest circumstance,

And modesty an exile made, for money?” (III vii 133-138)

Regarding the situation of Celia, it may be stated that this scene is the climax of the moral exposure that the play affords.

Degeneracy and innocence are brought together to emphasise the corruption of the world in which avarice and lust are the ruling passions. We can understand this very clearly. This passage moves at high speed, driven by Volpone's energy and ranging imagination, his flamboyant self-assurance and Dionysian sensuality.

"Thy baths shall be the juice of July-flowers,

Spirit of roses, and of violets

The milk of unicorns, and panthers' breath

Gathered in bags and mixed with Cretan wines.

Our drink shall be prepared gold and amber,

Which we will take until my roof whirl round

With the vertigo..." (III vii 213-219)

We see here the magnificence of Volpone's treasure more than at any other time. Mosca retains his presence of mind, as his politic, obsequious contrition shows.

“...... .if my heart

Could expiate the mischance, I'd pluck it out.

Will you be pleased to hang me, or cut my throat?" (III viii 11-13)

Volpone, on the other hand, is reduced to inactivity by his fear and discomfiture. 
The Linking Between the Emerging Market Economy and Human Character in Volpone of Ben Jonson

"I hear some footing; officers, the Saffi,

Come to apprehend us! I do feel the brand

Hissing already at my forehead; now,

Mine ears are boring............." (III viii 16-19)

Mosca, realizing the importance of Volpone preserving his 'shape', urges him to hide in the bed, and there he stays, unheeded by the visitors who now appear. Mosca lies to Corbaccio but is overheard by Voltore and needs all his skill in quick fiction to turn the lawyer's suspicion into gratitude and co-operation. This is perhaps the peak of Mosca's ingenuity in invention and in marrying his inventions to the already complicated narrative. Each in turn is convinced that he alone will inherit Volpone's wealth. The whole conspiracy is a frightening gamble. The fool is Volpone himself. By the end of III ix, (in the scene Jonson clarifies us never to trust someone like Volpone, an enthusiastic person with a gift for deceit, and he will endeavor to demonstrate that, in the end, humans like Volpone are always done in, commonly by their own decision to trust someone) we find Volpone again among the gulls, as each of them is stupidly confident of inheriting, so Volpone believes all is still well for him. The court itself, irremediably obtuse and unable to distinguish worth from wealth, would no doubt have come to a second false verdict had not Mosca, too, made a serious misjudgement in treating Volpone as he has treated Corbaccio and the others. The last speech of Avocatore, addressed to both auditors and offenders, points a moral in a way that hints at Jonson's conception of the didactic function of comedy. "The sentences themselves, in which the punishments exquisitely fit the crimes, are unashamedly those of the dramatist rather than the obtuse magistrates of Venice." (Barton, 1984: 117)

Lady Would Be is powerless in doing anything to the purpose, and when she plays into Mosca's hands in the fourth act, she becomes the most egregious of the dupes as she is the blindest. She is one of the persistent instruments of satire.

The play concentrates upon negatives, every man is either a knave or a fool, degenerate or deluded, sometimes both. There is no positive set of values against these negative ones. The play's world is unmistakably rich and splendid, but it is depraved, a world of imposture held up by credulity. Avarice and stupidity rob men of their humanity, and there is no sufficiently positive strength to be found in the slight figures of Celia and Bonario. Their names mark them as good characters. These characters are all simply part of the total design. Further comedy often focuses attention on groups of people or societies, not on individuals.

If it is to be critical, it does not have the scope to build up convincing virtuous parties. It relies upon the response of the orthodox morality in its audience. Each character shows himself deceived in estimating his own security. Thus, each of Volpone's clients believes himself the sole heir and thinks the other mistaken. Volpone and Mosca watch their antics 
and exploit their errors. Similarly, Volpone believes himself the controlling power, but Mosca knows otherwise and takes advantage of him.

Within the play, Mosca is the master knave, though he blunders at times, and in the end, badly misjudges his master. We see in the whole story that no one is secure, not even Mosca. Jonson provides, within the play, words which, unknown to the speaker, express our judgements. This is what happens when Volpone directs Mosca to tell enquirers that his supposedly dead body was corrupted, and Mosca concurs:

'I'll say it stunk, sir; and was fain t'have it

Coffined up instantly and sent away." (V ii 78-79)

The corruption in the world of the play is repetitively displayed as a consequence of unnatural conduct, which includes denial and misrepresentation of the truth, and without truth, all the conduct of mankind are craft and malice. We may go on extracting morals like this, but in fact, little doctrine survives our reading of the play or visiting the theatre. For this, there are four reasons. The characters have no existence outside the play, the vicious defeat themselves, so there is no continuing problem. The play as a whole is so superbly fashioned and finished that its completeness in itself is absolute. It is this last characteristic and the fact that we, too, live in a very acquisitive society, that makes it so satisfying a play. The aptness of Corvino's sentence, for instance, is so exact because of the systematic demonstration we have had of his stupidity and his false notion of honour.

“..............Thou, Corvino, shalt

Be straight embarked from thine own house, and rowed

Round about Venice, through the Grand Canal,

Wearing a cap with fair long ass's ears

Instead of horns; and so to mount, a paper

Pinned on thy breast, to the Berlina - " (V xii 134-139)

The speed with which the action develops makes the demonstration the more effective by bringing cause and effect very close together. Details are used to strengthen this effect of completeness, as when, for example, we discover, incidentally, a source of Volpone's regular income.

“............it was, in Volpone's time,

Your predecessor, ere he grew diseased,

A handsome, pretty, customed bawdy-house

As any was in Venice - none dispraised -

But fell with him. His body and that house 
The Linking Between the Emerging Market Economy and Human Character in Volpone of Ben Jonson

Decayed together... $"(\mathrm{~V}$ vii $10-15)$

Sometimes the neatness shows the bitter, as when Bonario breaks in to thwart Volpone. This sense of the supremely well-made play carries with it the recognition that it was shaped by a sane, penetrating mind, a judging intelligence that was serious without being solemn. To look at another aspect, it can be said that in Volpone corruption has been transferred to the sphere of family relations. The characters in Volpone sometimes strike us as perplexingly flat outlines as opposed to individuals because Jonson has forced them to exist in a material world so dense and detailed that it constantly threatens to overwhelm them in its sheer variety and proliferation.

These scenes are indicating how much Jonson a majestic satirist is, and an expert in style. As it is clear from the analysis made above, his work Volpone, shows us in which manner his relatives (so called a group of crooks) are tricked by a master trickster, and virtue receives its reward while evil is punished by evil.

\section{Was Jonson Really Against Capitalism?}

We may state that Jonson is a particularly striking specimen of early hostility to the market economy. He appears to have continued a large part of his career in reaction to and rebelling against, which can be described as his lower middle-class origins. His stepfather was a bricklayer, and, by following in his footsteps, Jonson was subjected to the world of trade early in his life. Luckily, Jonson received an excellent education at the famous Westminster School in London, and when he was presented with the opportunity, he pursued the typical middle- class path of rising in the society by utilising his wits and education. He aimed to clean the theatre of what he perceived to be its vulgarity, conceiving of himself as the playwright who would restore classical dignity to drama, in part by deliberately imitating Roman models in several of his plays. Jonson was the first English playwright to issue a published edition of his plays (in 1616), no doubt with a view to providing that his works were not the ephemeral products of the entertainment market place but literature of permanent worth.

Generally speaking, we may state that Jonson appears to have had a spark of the idea of spontaneous order as it was to be developed in the twentieth century. Jonson had developed the critique of the nascent market economy of the Renaissance in earlier plays such as Volpone. As in the cases of many contemporaries of his, Jonson was especially doubtful of the move in his day from a conception of wealth based on land to one based on money. The world he created is the world of money or food or sensual experience, regarded as divine. We can easily see such values, mostly in Volpone. In Volpone, he ridicules the way Money produces money in the devious schemes of Volpone and Mosca, who seem to be absolutely unproductive and living like parasites off the wealth of others. The play Volpone provides the evidence how the craving for wealth directs a person (maybe, frequently a society as a whole) to lose his way. Volpone, which was first written and performed in 1605-1606 depicting elements of city comedy and beast fable, is a harsh satire of greed and lust; it stays Jonson's most-performed play. 


\section{Conclusion}

There are many discussions that have been made on whether Jonson was against capitalism or not. He criticized it, I think, because of that he was a good man who could write in that manner, as well as being a good poet. For example, Loxley (2002:161) argued the theme about the values created by Jonson. As he describes this situation he says:" the people worship God, but they live as though they worship money, food and sexual experience. These are regarded as divine." Jonson created these values dramatically. Furthermore, Jonson recognised instinctively that the dislocation and separation of the human subject are functionally associated with historical disjunction in the social order of reality.

In terms of the growth of the market economy, L. C. Knight had related Jonson to the economic background of the time. In particular, the development of new capitalist means of organising the production and exchange of commodities, a new identification of wealth and power with money. These changed social circumstances saw a new class, the Bourgeoisie, beginning to emerge to challenge the aristocracy and landed gentry. On the one hand, L. C. Knight gave merely economic reasons for the tendency of Jonson towards writing such plays. On the other hand, Dutton (2000: 7) dwelled on the technical and social development of the time in which Jonson appeared. The discussion between Don E. Wayne and L. C. Knight is based on the socio-economic view of classic Marxism. Wayne sees him as the signal of changes in the society, but Knight describes him as a poet of traditional Christian humanist values. Wayne argues that Jonson considered himself later as a person who is psychologically and socially alienated in a market-place economy.

Wayne goes further and questions the terms in which Knight had earlier proposed Jonson's centrality. Wayne argues (1982:27-28): "“the Jacobean theatre is represented as a place where author and audience are joined in the communal celebration of a traditional code". What is being argued by him is that the dramatists are caught in something of a double bind themselves in relation to the place of their own work in this novel economic, political and social environment. Wayne himself recommends that, after the early theatrical triumphs of Jonson, he began to show indications of a disturbed awareness that his own identity as a poet and playwright relied upon the identical emerging structure of social interactions that he satirized in his plays. It is right to say that what happened in the society is usually the subject of literature. Moreover, we know that Wayne is interested in the way that literature reflects the social consequences of the changing economic base created by capitalism. In this connection, Jonson lived in a rigid social hierarchy, and he wrote about it. This is why we cannot easily say that Jonson created something that never existed.

Even though it is difficult to say with certainty that Jonson was against the capital system, it is possible to describe/presuppose, at least, the condition he lived in, which could have pushed him to the anticapitalistic standpoint. As the assertions made by Riggs show, Jonson was surrounded by margins of destitution and prosperity from the initial parts of his life (Riggs: 1989) that gave him the opportunity to be familiar with 
The Linking Between the Emerging Market Economy and Human Character in Volpone of Ben Jonson

contradictions that the society possessed. We see that, usually, the critics have located in the Jonsonian structure of authorship and its authority, which is not stable. Here, Wayne takes it up as a means of describing the inadequacy of the basis on which ethical accounts of the plays are set. What Knights describes as an essentially ethical concern, acquisitiveness, Wayne locates within the complex transformations of human identity and relationships. He suggests that these are brought about by the development of new socio-economic processes.

Volpone (the Fox), as the name suggests, is a simple dramatic character. He is a trickster who delights in disguises and trickery. His actions are complex in plot but simple in the psychology of the character that executes them. Volpone loves to trick people into giving him their most prized possessions. When he has safeguarded these through cunning rather than ordinary means, the value is boosted in the fox's eyes. his character assets the humiliation of those he has cozened more than the wealth received as a result of the cozening. In short, Volpone, with his character, gives a representation from the capitalized world in that period, as result of market economy.

\section{References}

Barton, Ann. (1984). Ben Jonson, Dramatist. Cambridge University Press.

Bevington, D., M. (1979). "Projects and Information: Library (1979) s6-I (4): 410" (PDF). Library.oxfordjournals.org. Retrieved 2017-01-09

Dutton, Richard. (2000). Ben Jonson. Longman Critical Reader.

Graham, C.B. (1947). “The Jonsonian Tradition in the Comedies of Thomas D'Urfey”. Modern Language Quarterly, viii, 47-52.

Hayness, J. (1992). The Social Relations of Jonson's Theater. Cambridge University Press.

Herford, C., \& H., Simpson., \& P., Simpson, E. (Eds.). (1950). Ben Jonson. Oxford University Press.

Knights, L. C. (1957). Drama and Society in the Age of Jonson. Chatto and Windus.

Kent, L. M. (2007). The British Enlightenment and the Spirit of the Industrial Revolution: The Society for the Encouragement of Arts, Manufactures and Commerce (1754-1815). ProQuest Information and Learning Company.

Lyly, John. (1996). “Endymion”. In D. M. Bevington (Eds.). The Revels Plays. 1-72 Manchester University Press.

Miller, T. S. (1907). "The Case of the Monopolies: Some of Its Results and Suggestions", $M^{\prime} c$ /7/ güw Law Review, 6(1), 1-24.

Parker, B. (1999). Volpone by Ben Jonson. Manchester University Press. 
Riggs, D. (1989). Ben Jonson: A Life. Harvard University Press.

Sidney P., Ed. (1906), Conversation of Ben Jonson with William Drummond. Gay and Bird.

Stout, M. (1988). Volpone by Jonson. Houndmills, Basingstoke, Hampshire RG212XS and London: Macmillan Education Ltd.

Rorabacher, J. Albert. (2017). Property, Land, Revenue, and Policy: The East India Company, C.1757-1825. London and New York: Routledge Taylor and Francis Group.

Venables, M. (1970). Jonson Volpone and Alchemist. Blackwell Publisher.

Wayne, Don. (1982). "Drama and Society in the Age of Jonson: An Alternative View." Renaissance Drama 13.

\section{Additional References}

Barish, Jonas A. (1963). Ben Jonson: A Collection of Critical Essays. Prentice-Hall Inc.:, NJ.

Barish, Jonas A. (Ed.). (1993). Jonson: Volpone. Casebooks.

Creaser, Jone W. (Ed.). (1978). Ben Jonson, Volpone, or The Fox. Hodder and Stoughton.

Cave, Richard Allen. (1991). Ben Jonson. St. Martin ‘s Press.

Greenblatt, Stephen J. (1974). "The False Ending in Volpone" Journal of English and Germanic Philology 74.

Harp, Richard \& Stewart, Stanley. (Eds.). (2000). The Cambridge Companion to Ben Jonson. Cambridge University Press.

Jamieson Michael. (1966). Ben Johnson Three Comedies. Penguin Literature Drama, Penguin Book LTD.

Loxey, James. (2002). The Complete Critical Guide to Ben Jonson. London: Routledge. 